\title{
Hospital Beds in the United States
}

\section{in 1953}

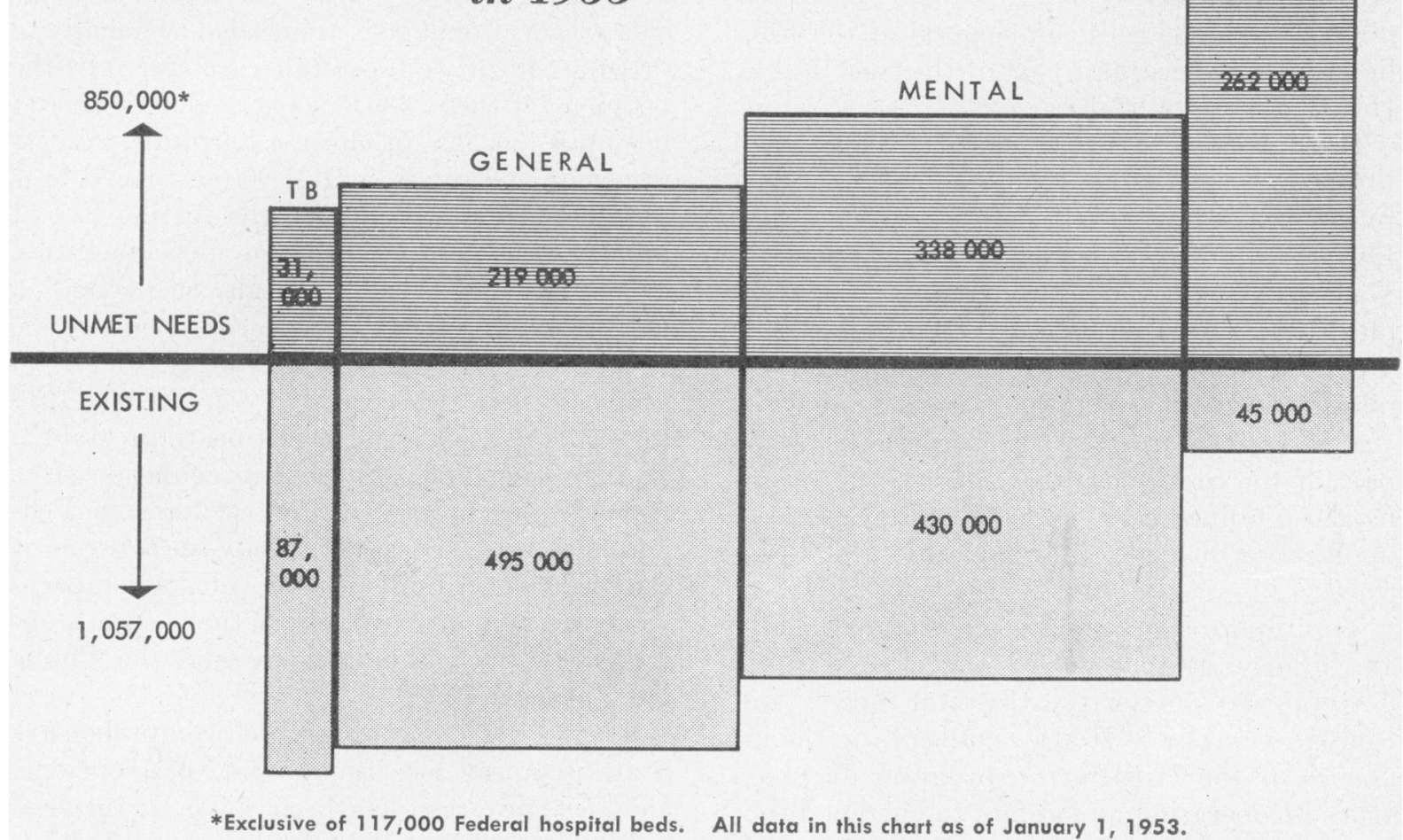

\section{BY JOHN W. CRONIN, M.D., MAURICE E. ODOROFF, M.A., and LESLIE MORGAN ABBE, B.S.}

$\mathrm{H}^{\circ}$

OSPITAL BEDS are symbols of hospital services and are not an end in themselves. They do provide a useful measure of the physical facilities at hand for furnishing hospital services. The capacity to provide adequate health care in a community or a nation can be gauged substantially by the number of beds available, in relation to the number of people living in the area.

Prior to 1946 the building of new hospitals and hospital additions in the United States was

Dr. Cronin is chief of the Division of Hospital Facilities, Public Health Service. Mr. Odoroff is chief and Mr. Abbe is assistant chief of the program evaluation and reports branch of the division. sporadic, proceeding slowly in some communities and rapidly in others, according to local pressures and means and without regard to any general pattern or orderly plan. At the same time many communities and sections of the Nation had little or no available hospital care within ready reach. The end of World War II made possible a renewed interest in providing for many domestic needs. Physical facilities for the Nation's health became one aspect of this interest.

A broad program was launched in 1946 by Federal legislation to assist the States to inventory their existing hospitals, to define the total need for hospitals, and to map out a construction program to provide needed hospital and health center services. Financial assist- 
ance was included, both for planning and construction. This legislation, the Hospital Survey and Construction Act (Public Law 725, 79th Cong.) has been popularly known as the Hill-Burton Act. Its administration was placed under the Surgeon General of the Public Health Service, as a part of the basic Public Health Service Act.

It required more than a year to develop initial inventories and comprehensive plans. Hospital inventories existed, compiled by the American Hospital Association and the American Medical Association, but the idea of inventoryplus-statewide-program was entirely new. The first complete set of these comprehensive plans reflected the facts as of about January 1, 1948. Today, after 5 years of experience on the part of the State hospital agencies, the record has been refined and general planning is based upon more intimate knowledge of local situations.

This report appraises the situation nationally and locally, as reflected by the current State hospital plans under the Hospital Survey and Construction Act. It also comments on the influence of the Hill-Burton program during 5 years of operation and refers to current problems relating to standards of need and standards for the degree of Federal aid now appropriate.

\section{Where We Are Now}

In the Nation as a whole we now have 1,218,000 existing hospital beds, according to State plan inventories as of January 1, 1953. These plans excluded Federal beds. This total is 202,000 more than was recorded in the first Hill-Burton inventory as of January 1, 1948. Of these, however, 161,000 beds are classified by the State agencies as nonacceptable on the basis of fire and health hazards, so that our net acceptable plant for all purposes is $1,057,000$ beds. Almost one-half of this total, or 495,000 beds, is in general hospitals; mental hospitals have 431,000 beds ; tuberculosis hospitals, 86 ,000 beds; and hospitals for chronic care, 44,000 beds.

The Hospital Survey and Construction Act establishes standards of need, for planning purposes, in each category of hospital. These standards are limits for construction with Fed- eral assistance and do not preclude State planning to higher levels if warranted. For most States, however, the standards established in the Hill-Burton Act are much beyond the level of existing facilities. By these standards about 850,000 additional beds are needed nationally to provide adequate hospital care for all the people. Of these, 336,000 are needed in mental hospitals, 262,000 in chronic hospitals, 219,000 in general hospitals, and 31,000 in tuberculosis hospitals. Percentagewise, the Nation has 77 percent of its need met in tuberculosis facilities, 69 percent in general hospitals, 56 percent in mental hospitals, and 14 percent in chronic hospitals.

The historical record, by years from 1948 to 1953 , for each category appears in table 1 . By definition under the present regulations, this inventory excludes beds for civilians in Federal hospitals. These are chiefly in facilities of the Veterans Administration, plus a comparatively small number of beds in the hospitals operated by the Indian Service and the Public Health Service.

During the 5 years for which comprehensive State planning has been carried on, considerable net progress has been made in general hospitals: 107,000 additional acceptable beds are recorded, a gain of 28 percent. Tuberculosis beds have also increased more than 20 percent. Mental and chronic beds, on the other hand, while increasing slowly, are not keeping up with growth in population and obsolescence. In both these categories the remaining need is greater than in 1948. This constitutes one of the major challenges facing the Nation today in meeting the need for adequate hospital services.

National trends and national totals do not accurately reflect the real picture in regard to specific regions of the country. Among the States, wide differences exist as to relative status in providing an adequate hospital plant. Similar differences exist among the major socioeconomic regions of the Nation. Generally speaking, the States with large means have the least unmet need, while the least wealthy States have the greatest need. Thus, New York and Connecticut have only about 3.2 beds per 1,000 population still required, for all purposes. Mississippi and Alabama each need 8.3 more 
beds per 1,000 population, while the national average of unmet need is 5.5 beds per 1,000 population. Regionally, the greatest unmet need for general hospitals is still in the southeastern States, although substantial progress has been made here during the past 5 years.

Similar contrasts appear for mental hospitals. The unmet need, nationally, is still 2.2 beds per 1,000 population. In New England it is only 1 bed per 1,000 , but throughout the southeastern and southwestern States this need is nearly 3 beds per 1,000 . Comparative positions are shown in the maps and in table 2.

The Hospital Survey and Construction Act requires that a coordinated system of general hospitals be planned within each State, under

Table 1. Civilian hospital beds in the United States and Territories, 1948-53

\begin{tabular}{|c|c|c|c|c|c|c|}
\hline \multirow{3}{*}{$\begin{array}{l}\text { Hospital category and year } \\
\text { (as of Jan. 1) }\end{array}$} & \multirow{3}{*}{$\begin{array}{l}\text { Estimated } \\
\text { total beds } \\
\text { needed } 1\end{array}$} & \multicolumn{4}{|c|}{ Existing beds } & \multirow{3}{*}{$\begin{array}{c}\text { Estimated } \\
\text { additional } \\
\text { beds needed }\end{array}$} \\
\hline & & \multirow{2}{*}{ Total } & \multirow{2}{*}{$\begin{array}{l}\text { Nonaccept- } \\
\text { able }^{2}\end{array}$} & \multicolumn{2}{|c|}{ Acceptable } & \\
\hline & & & & Number & $\begin{array}{l}\text { Percent of } \\
\text { total need }\end{array}$ & \\
\hline \multicolumn{7}{|l|}{ All categories } \\
\hline $\begin{array}{l}1953 \\
1952 \\
1951 \\
1950 \\
1949 \\
1948\end{array}$ & $\begin{array}{l}1,899,279 \\
1,899,806 \\
1,883,487 \\
1,850,052 \\
1,776,673 \\
1,776,401\end{array}$ & $\begin{array}{l}1,218,781 \\
1,193,836 \\
1,185,480 \\
1,118,535 \\
1,025,179 \\
1,016,712\end{array}$ & $\begin{array}{l}161,354 \\
176,013 \\
175,562 \\
166,339 \\
145,307 \\
148,752\end{array}$ & $\begin{array}{r}1,057,427 \\
1,017,823 \\
1,009,918 \\
952,196 \\
879,872 \\
867,360\end{array}$ & $\begin{array}{l}\text { 55. } 7 \\
\text { 53. } 6 \\
53.6 \\
51.5 \\
49.5 \\
48.9\end{array}$ & $\begin{array}{l}848,567 \\
881,983 \\
873,569 \\
897,856 \\
896,801 \\
908,441\end{array}$ \\
\hline \multicolumn{7}{|l|}{ General hospitals } \\
\hline $\begin{array}{l}1953 \\
1952 \\
1951 \\
1950 \\
1949 \\
1948\end{array}$ & $\begin{array}{l}714,469 \\
708,574 \\
700,952 \\
682,601 \\
652,611 \\
652,974\end{array}$ & $\begin{array}{l}572,493 \\
554,084 \\
548,798 \\
513,814 \\
474,532 \\
469,398\end{array}$ & $\begin{array}{l}77,308 \\
79,750 \\
79,606 \\
76,028 \\
77,364 \\
81,254\end{array}$ & $\begin{array}{l}495,185 \\
474,334 \\
469,192 \\
437,786 \\
397,168 \\
388,144\end{array}$ & $\begin{array}{l}\text { 69. } 3 \\
66.9 \\
66.9 \\
64.1 \\
60.9 \\
59.4\end{array}$ & $\begin{array}{l}219,222 \\
234,240 \\
231,760 \\
244,815 \\
255,443 \\
264,830\end{array}$ \\
\hline \multicolumn{7}{|l|}{ Mental hospitals } \\
\hline $\begin{array}{l}1953 \\
1952 \\
1951 \\
1950 \\
1949 \\
1948\end{array}$ & $\begin{array}{l}766,463 \\
755,097 \\
744,323 \\
725,203 \\
692,150 \\
690,381\end{array}$ & $\begin{array}{l}490,598 \\
482,733 \\
483,310 \\
462,859 \\
428,931 \\
427,201\end{array}$ & $\begin{array}{l}59,591 \\
69,801 \\
67,780 \\
63,721 \\
47,304 \\
46,858\end{array}$ & $\begin{array}{l}431,007 \\
412,932 \\
415,530 \\
399,138 \\
381,627 \\
380,343\end{array}$ & $\begin{array}{l}\text { 56. } 2 \\
\text { 54. } 7 \\
\text { 55. } 8 \\
\text { 55. } 0 \\
\text { 55. } 1 \\
\text { 55. } 1\end{array}$ & $\begin{array}{l}336,676 \\
342,165 \\
328,793 \\
326,065 \\
310,523 \\
310,038\end{array}$ \\
\hline \multicolumn{7}{|l|}{ Tuberculosis hospitals } \\
\hline $\begin{array}{l}1953 \\
1952 \\
1951 \\
1950 \\
1949 \\
1948\end{array}$ & $\begin{array}{l}112,075 \\
133,899 \\
140,391 \\
148,936 \\
155,101 \\
155,987\end{array}$ & $\begin{array}{r}100,204 \\
99,147 \\
96,955 \\
94,024 \\
85,466 \\
84,158\end{array}$ & $\begin{array}{l}13,506 \\
11,597 \\
11,604 \\
12,513 \\
12,906 \\
13,007\end{array}$ & $\begin{array}{l}86,698 \\
87,550 \\
85,351 \\
81,511 \\
72,560 \\
71,151\end{array}$ & $\begin{array}{l}77.4 \\
65.4 \\
60.8 \\
54.7 \\
46.8 \\
45.6\end{array}$ & $\begin{array}{l}30,934 \\
46,349 \\
55,040 \\
67,425 \\
82,541 \\
84,836\end{array}$ \\
\hline \multicolumn{7}{|l|}{ Chronic hospitals } \\
\hline $\begin{array}{l}1953 \\
1952 \\
1951 \\
1950 \\
1949 \\
1948\end{array}$ & $\begin{array}{l}306,272 \\
302,236 \\
297,821 \\
293,312 \\
276,811 \\
277,059\end{array}$ & $\begin{array}{l}55,486 \\
57,872 \\
56,417 \\
47,838 \\
36,250 \\
35,955\end{array}$ & $\begin{array}{r}10,949 \\
14,865 \\
16,572 \\
14,077 \\
7,733 \\
7,633\end{array}$ & $\begin{array}{l}44,537 \\
43,007 \\
39,845 \\
33,761 \\
28,517 \\
28,322\end{array}$ & $\begin{array}{l}14.5 \\
14.2 \\
13.4 \\
11.5 \\
10.3 \\
10.2\end{array}$ & $\begin{array}{l}261,735 \\
259,229 \\
257,976 \\
259,551 \\
248,294 \\
248,737\end{array}$ \\
\hline
\end{tabular}

' As set by Title VI of Public Health Service Act.

2 As classified by State agencies, on the basis of fire and health hazards.

Source: State Plans for Hospital Construction. 


\section{Remaining}

Need

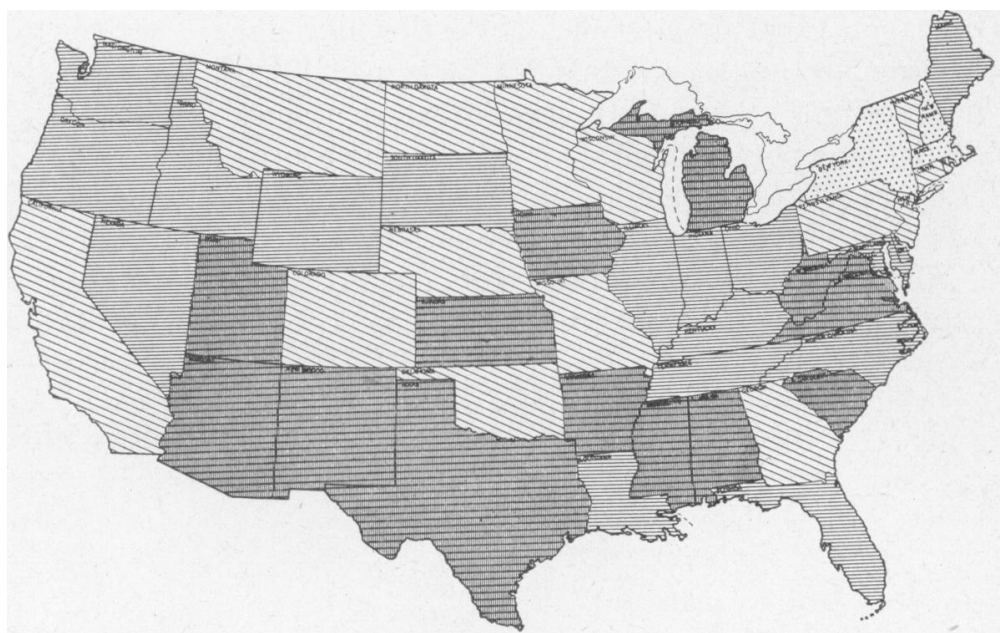

for

\section{Mental}

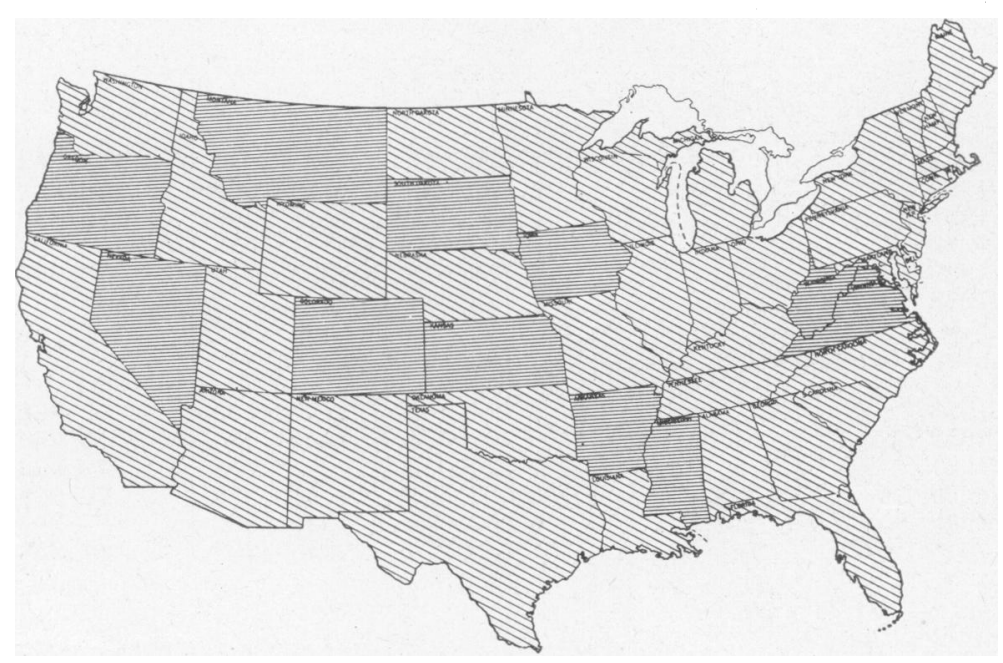

Chronic Disease

which regional hospital centers would provide leadership, specialized care, and consultation for smaller community hospitals within the region. Under the Hill-Burton program the United States is composed of 375 such regions, as defined in present State plans. Studies of these regions show that there are actually wide differences as to the level of facilities now available in single hospital regions. In Arkansas the proportion of acceptable facilities available varies from region to region, from about 25 percent of need met to nearly 75 percent. In Florida, it ranges from 42 percent to 87 percent; in Kansas, from 52 percent to 92 percent; and in Idaho, from 45 percent to 96 percent. Obviously, State totals may obscure important differences among hospital regions in the present available plant.

For local communities there are also areas of acute need with little or no available hospital plant. A recent check shows 250 hospital areas still without any acceptable hospital facilities. These areas include about 3 percent of the Nation's population and require some 13,000 beds to meet standards for general hospital care. This study also shows that about 5 percent of the population of the Nation live in areas where less than 25 percent of the general hospital facilities needed are available. These facts give some indication of the work yet to be done. 


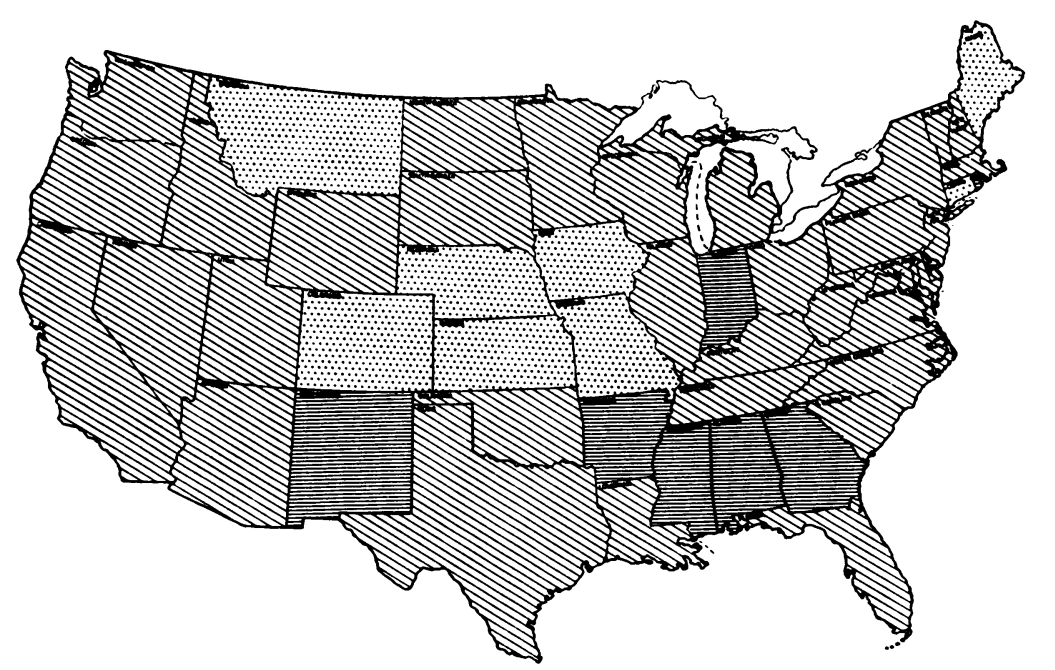

\section{Rate per 1,000}

\section{Population}

\section{General}

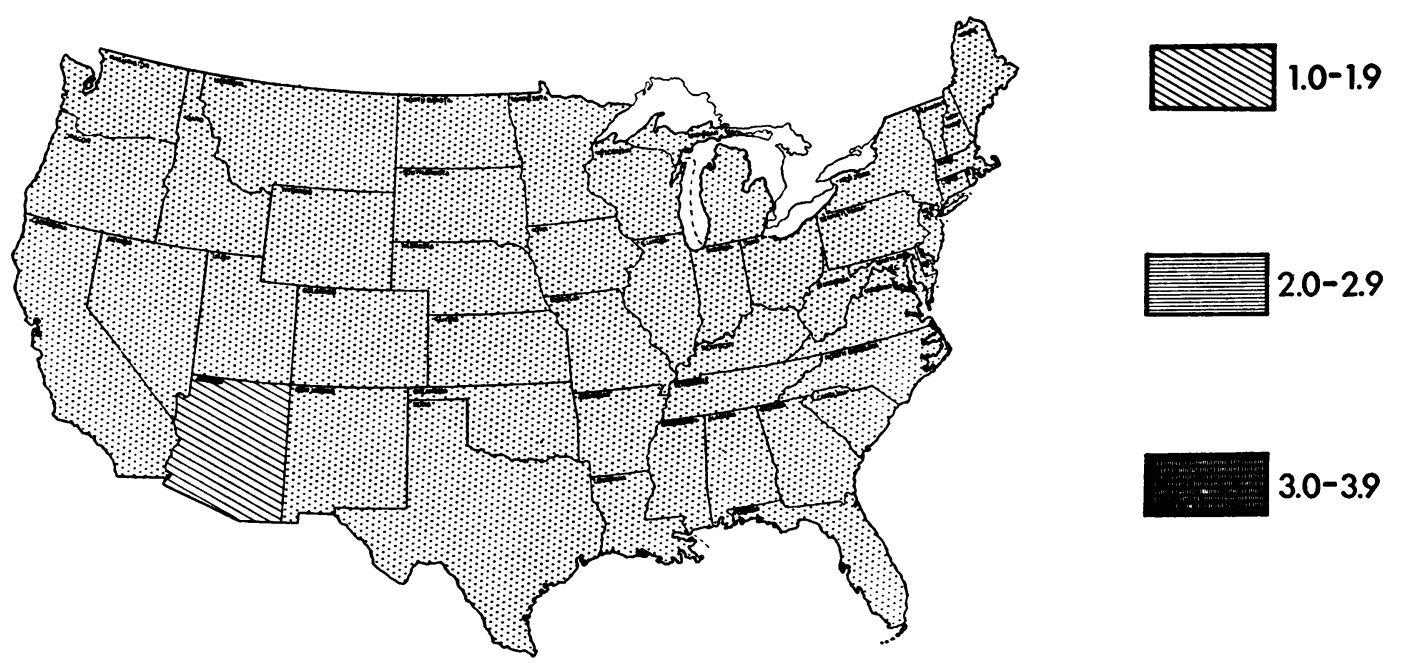

Tuberculosis

\section{Effect of the Hill-Burton Program}

The act requires a continuous inventory and positive planning of hospital expansion in each State. This has greatly stimulated orderly growth of the Nation's facilities for protecting the health of its people. Its direct encouragement of construction has been substantial, when measured by the dollar volume of hospital construction $(1, \mathscr{2})$. During the last 3 years the value of work placed on Hill-Burton projects has averaged about one-third of all non-Federal hospital construction (see chart).

A number of additional benefits also have accrued (3). Perhaps the most significant, in regard to improving the quality of service, have been the very rapid increase in State statutes establishing hospital licensing, improved architectural design, attracting of physicians to rural communities, and creating a greater awareness of the problems of adequate care for chronic illness.

The effect of the hospital survey and construction program is quite significant in regard to the distribution of projects assisted. This is governed by the statutory formula for allocation among the States of the annual appropriation and by the conditions required as to a graduated scale for matching local funds. In each State, the formula for matching is based on population, weighted by its financial ability. As a result, the greatest Federal assistance has 
Table 2. Additional needs for hospital beds in the United States as of January 1, 1953, according to State hospital plans approved under the Hill-Burton Act

\begin{tabular}{|c|c|c|c|c|c|c|}
\hline \multirow{2}{*}{$\begin{array}{l}\text { State and socioeconomic } \\
\text { region }\end{array}$} & \multirow{2}{*}{$\begin{array}{l}\text { Civilian } \\
\text { population } \\
\text { per plan } \\
\text { (thousands) }\end{array}$} & \multicolumn{5}{|c|}{ Additional beds needed-rate per 1,000 population } \\
\hline & & All hospitals & General & Mental & Chronic & Tuberculosis \\
\hline $\begin{array}{c}\text { United States and } \\
\text { Territories. }\end{array}$ & 153,260 & 5. 5 & 1.4 & 2.2 & 1.7 & 0.20 \\
\hline New England. & 9, 312 & 3.8 & 1.5 & 1.0 & 1.2 & .02 \\
\hline Connecticu & 2,026 & 3. 2 & .9 & 1. 1 & 1.2 & \\
\hline Maine & 912 & 5. 1 & .9 & 2. 3 & 1. 8 & \\
\hline $\begin{array}{l}\text { Massachusetts } \\
\text { New Hampshi }\end{array}$ & $\begin{array}{l}4,691 \\
531\end{array}$ & $\begin{array}{l}3.7 \\
4.2\end{array}$ & $\begin{array}{l}1.8 \\
1.5\end{array}$ & .7 & 1.2 & 14 \\
\hline Rhode Island. & 774 & $\begin{array}{l}\text { 4. } 2 \\
\text { 3. } 5\end{array}$ & 2. 0 & 1. 2 & $\begin{array}{l}1.9 \\
.3\end{array}$ & .01 \\
\hline Vermont & 378 & 4. 9 & 1. 6 & 1.3 & 1. 9 & .15 \\
\hline $\begin{array}{l}\text { Middle East } \\
\text { Delaware }\end{array}$ & 36,117 & 4.4 & 1.3 & 1.4 & 1.6 & .20 \\
\hline $\begin{array}{l}\text { Delaware } \\
\text { District of Colu }\end{array}$ & $\begin{array}{l}318 \\
769\end{array}$ & 4.7 & .4 & 2. 9 & .9 & .52 \\
\hline Maryland & 2,306 & $\begin{array}{l}3.2 \\
4.6\end{array}$ & 1. 1 & 2.0 & $\begin{array}{l}1.8 \\
1.2\end{array}$ & .31 \\
\hline New Jersey & 4,972 & 4. 9 & 1.5 & 1.6 & 1.7 & 04 \\
\hline New York & 15,267 & 3. 3 & 1.0 & .7 & 1.4 & 14 \\
\hline Pennsylvan & 10,480 & 5.4 & 1.6 & 1.7 & 1.9 & 35 \\
\hline $\begin{array}{l}\text { West Virginia } \\
\text { Southeast }\end{array}$ & 2,005 & 7.4 & 1.7 & 3. 6 & 2.0 & .06 \\
\hline $\begin{array}{l}\text { Southeast } \\
\text { Alabama }\end{array}$ & $\begin{array}{r}31,471 \\
3,053\end{array}$ & 6.8 & 1.8 & 2.9 & 1.8 & .26 \\
\hline $\begin{array}{l}\text { Alabama_- } \\
\text { Arkansas }\end{array}$ & $\begin{array}{l}3,053 \\
1,908\end{array}$ & $\begin{array}{l}8.3 \\
7.6\end{array}$ & $\begin{array}{l}\text { 2. } 0 \\
\text { 2. } 0\end{array}$ & $\begin{array}{l}\text { 3. } 9 \\
\text { 3. } 6\end{array}$ & $\begin{array}{l}1.9 \\
2.0\end{array}$ & .53 \\
\hline Florida & 2,729 & 5.8 & 1.5 & 2. 7 & 1. 7 & \\
\hline $\begin{array}{l}\text { Georgia.... } \\
\text { Kentucky }\end{array}$ & $\begin{array}{l}3,418 \\
2,913\end{array}$ & $\begin{array}{l}5.6 \\
7.1\end{array}$ & $\begin{array}{l}2.2 \\
1.9\end{array}$ & 1.8 & 1. 6 & .07 \\
\hline $\begin{array}{l}\text { Kentucky - } \\
\text { Louisiana_. }\end{array}$ & $\begin{array}{l}2,913 \\
2,670\end{array}$ & $\begin{array}{l}7.1 \\
6.3\end{array}$ & $\begin{array}{l}1.9 \\
1.3\end{array}$ & $\begin{array}{l}2.8 \\
2.8\end{array}$ & $\begin{array}{l}1.9 \\
1.9\end{array}$ & $\begin{array}{l}.58 \\
.22\end{array}$ \\
\hline Mississipp & 2,169 & 8.3 & 2.3 & 3. 5 & 2. 0 & .47 \\
\hline North Ca & 4,014 & 6. 3 & 1. 6 & 2.8 & 1.9 & \\
\hline $\begin{array}{l}\text { South Caroli } \\
\text { Tennessee }\end{array}$ & $\begin{array}{l}2,096 \\
3,281\end{array}$ & 7. 0 & 1.7 & 3. 2 & 1.9 & $\begin{array}{r}19 \\
47\end{array}$ \\
\hline $\begin{array}{l}\text { Tennessee... } \\
\text { Virginia... }\end{array}$ & $\begin{array}{l}3,281 \\
3,220\end{array}$ & $\begin{array}{l}6.2 \\
7.1\end{array}$ & $\begin{array}{l}1.7 \\
1.8\end{array}$ & $\begin{array}{l}2.6 \\
3.0\end{array}$ & $\begin{array}{l}1.5 \\
2.0\end{array}$ & $\begin{array}{l}.47 \\
.37\end{array}$ \\
\hline Southwest & 11,247 & 6.3 & 1.2 & 2.9 & 1.9 & $\begin{array}{l}.37 \\
.30\end{array}$ \\
\hline Arizona & 777 & 7. 8 & 1.2 & 3. 7 & 1.8 & 1.03 \\
\hline New Mexic & $\begin{array}{r}668 \\
2218\end{array}$ & 8. 1 & 2.0 & 3. 6 & 1.9 & .59 \\
\hline Oklahoma & $\begin{array}{l}2,218 \\
7,584\end{array}$ & 4. 9 & 1.5 & 1.5 & 1.8 & .12 \\
\hline $\begin{array}{r}\text { Texas...... } \\
\text { Central }\end{array}$ & $\begin{array}{r}7,584 \\
39,893\end{array}$ & 6.4 & 1.1 & 3. 2 & 1.9 & .25 \\
\hline & $\begin{array}{r}39,893 \\
8,672\end{array}$ & 5.8 & 1.4 & 2.6 & 1.8 & 09 \\
\hline $\begin{array}{l}\text { Illinois...... } \\
\text { Indiana.... }\end{array}$ & $\begin{array}{l}8,672 \\
3,932\end{array}$ & $\begin{array}{l}\text { 5. } 6 \\
7.1\end{array}$ & $\begin{array}{l}1.2 \\
2.3\end{array}$ & 2.7 & 1. 6 & $\begin{array}{r}.11 \\
29\end{array}$ \\
\hline Ior & $\begin{array}{l}5,952 \\
2,621\end{array}$ & $\begin{array}{l}7.1 \\
6.6\end{array}$ & $\begin{array}{r}2.3 \\
.8\end{array}$ & $\begin{array}{l}2.0 \\
3.7\end{array}$ & $\begin{array}{l}1.9 \\
2.0\end{array}$ & $\begin{array}{l}.29 \\
.01\end{array}$ \\
\hline Michig & 6,361 & 6. 7 & 1.8 & 3. 1 & 1.8 & $\cdots$ \\
\hline Minnesota & 2,982 & 4. 7 & 1. 0 & 1.8 & 1.9 & \\
\hline Mis & 3,952 & 4. 6 & .9 & 1.8 & 1. 7 & .23 \\
\hline $\begin{array}{l}\text { Ohio_..... } \\
\text { Wisconsin }\end{array}$ & $\begin{array}{l}7,938 \\
3,435\end{array}$ & 5.9 & 1. 3 & 2.6 & 1.9 & .10 \\
\hline $\begin{array}{l}\text { Wisconsin } \\
\text { Northwest }\end{array}$ & $\begin{array}{l}3,435 \\
7,939\end{array}$ & 4. 7 & 1. 2 & 1.8 & 1.7 & 06 \\
\hline $\begin{array}{l}\text { Northwest } \\
\text { Colorado... }\end{array}$ & $\begin{array}{l}7,939 \\
1,307\end{array}$ & $\begin{array}{l}5.2 \\
4.1\end{array}$ & $\begin{array}{r}1.0 \\
.6\end{array}$ & $\begin{array}{l}2.3 \\
1.6\end{array}$ & $\begin{array}{l}1.8 \\
2.0\end{array}$ & .06 \\
\hline Idaho & 588 & 6. 5 & $\begin{array}{l}.0 \\
1.6\end{array}$ & 2. 9 & 1. 9 & 12 \\
\hline & 1,905 & 6.2 & .9 & 3. 3 & 2.0 & .01 \\
\hline Montana. - & 589 & 4.4 & .7 & 1.7 & 2. 0 & \\
\hline $\begin{array}{l}\text { Nebraska } \\
\text { North Dakota }\end{array}$ & $\begin{array}{r}1,326 \\
605\end{array}$ & $\begin{array}{ll}3.7 \\
4.8\end{array}$ & .9 & 1.4 & 1.4 & .10 \\
\hline $\begin{array}{l}\text { North Dakota } \\
\text { South Dakota }\end{array}$ & $\begin{array}{l}605 \\
650\end{array}$ & $\begin{array}{l}4.8 \\
5.9\end{array}$ & $\begin{array}{l}1.5 \\
\text { 1. } 5\end{array}$ & $\begin{array}{l}1.4 \\
2.1\end{array}$ & $\begin{array}{l}1.8 \\
2.0\end{array}$ & 29 \\
\hline Utah & 687 & 6.7 & 1.4 & 3.3 & 1.9 & 08 \\
\hline Wyoming & 282 & 5.4 & 1.1 & 2. 5 & 1.8 & .06 \\
\hline Far West & 14,449 & 4.7 & 1.5 & 1.6 & 1.6 & .08 \\
\hline California & 10,421 & 4. 4 & 1.5 & 1.3 & 1.5 & .09 \\
\hline Nevada... & 166 & 6.5 & 1.5 & 2. 6 & 2. 0 & .43 \\
\hline $\begin{array}{l}\text { Oregon-.... } \\
\text { Washington }\end{array}$ & 1,519 & 5.7 & 1.5 & 2. 2 & 2.0 & .08 \\
\hline $\begin{array}{l}\text { Washington } \\
\text { Territories }\end{array}$ & 2,343 & 5. 6 & 1.5 & 2.4 & 1.7 & 20 \\
\hline $\begin{array}{l}\text { Territories. } \\
\text { Alaska.... }\end{array}$ & $\begin{array}{r}2,832 \\
129\end{array}$ & 9.9 & 2.1 & 3. 7 & 1.8 & $\begin{array}{r}2.29 \\
.72\end{array}$ \\
\hline $\begin{array}{l}\text { Alaska } \\
\text { Hawaii......... }\end{array}$ & $\begin{array}{l}129 \\
474\end{array}$ & $\begin{array}{l}7.6 \\
6.1\end{array}$ & $\begin{array}{l}\text { 3. } 1 \\
1.6\end{array}$ & 3. 1 & 1. 4 & .72 \\
\hline Puerto Rico & 2,203 & 10.9 & 2.2 & 4.0 & 1.9 & 2.88 \\
\hline Virgin Islands & 26 & 6.0 & & 4. 4 & & 1.55 \\
\hline
\end{tabular}


been given in the least wealthy States. The record shows that remaining need is still the greatest in these States.

Expressed broadly, the Hill-Burton program in 5 years has assisted in building about. 1.0 bed per 1,000 population in the neediest States. These are States where the remaining additional need is still about 8 beds per 1,000 population. A proportionally lesser volume of assistance-about 0.3 beds per 1,000 population-has been accorded States with the least unmet need. In these States the remaining need is now under 3.5 beds per 1,000 population. Comparative study of the relation between remaining need and the degree to which these States are rural in character shows that the greatest need occurs in those States which have the highest proportion of population living in rural areas. In brief, Hill-Burton aid has been distributed to the greatest degree in those States which are least wealthy, most rural, and with greatest proportional unmet need.

Within the several States, distribution of assistance to specific projects has been governed by a priority system based on unmet need, as established in the State plan. In consequence the stimulus of Federal assistance has encouraged many communities where unmet need was the greatest to raise local funds for matching Federal grants, in accordance with the intent of the act. Recent studies have indicated that 38 percent of all general hospital beds added with Hospital Survey and Construction Act assistance have been in places under 10,000 in population; 31 percent in places of from 10,000 to 50,000 population; and 31 percent in metropolitan cities of over 50,000 population. Nearly 600 new projects have been placed in communities which previously had no acceptable hospital. At the other end of the scale, 21 teaching facilities at university medical centers have been assisted in 18 States.

Major emphasis has been placed by State agencies on Hill-Burton assistance to general hospital projects. As of January 1, 1953, general hospital beds added by approved projects amount to 73,168 , of a total of 96,428 beds in all types of hospitals. A gradual change in this emphasis for most States appears important, if a reasonable balance between categories of facilities is to be attained.
Value of construction put in place

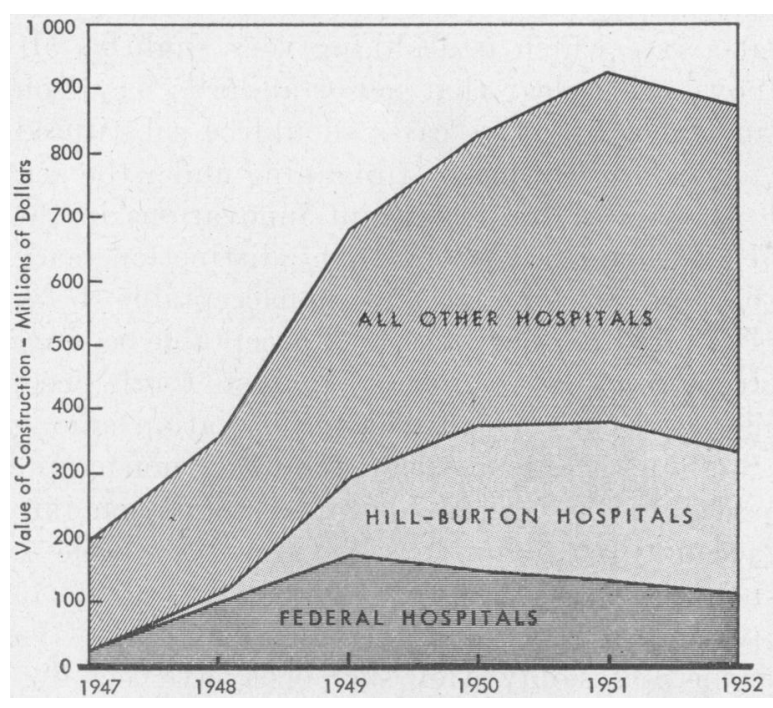

The hospital survey and construction program makes funds available not only for hospitals but for public health centers. In the Nation to date 377 such projects have been approved. The largest number of these, 283, will serve the $30,000,000$ people in the 11 southeastern States. In this region these projects constitute a substantial increase in facilities available for preventive medicine and extend a means of providing for good health at a very moderate outlay. These projects represent a total expenditure of $\$ 28,000,000$, or about 2 percent of the estimated total cost of $\$ 1,588,000,000$ for all projects assisted through January 1, 1953, by Hospital Survey and Construction Act funds.

\section{Problems Ahead}

After 5 years of active operation of this cooperative Federal-State program, problems are emerging which were not at first anticipated. One group of problems involves the technical aspects of setting more precise standards of need :

1. The standard for tuberculosis beds required, as gradually evolved since 1917 , is not on a population basis, but is related to the mortality rate. The mortality rate for tuberculosis continued to decline rapidly and dropped to a rate of 20 per 100,000 population for 1951 . This is in contrast to a rate of 46 in 1940 and 200 at 
the turn of the century. New cases of active tuberculosis, however, continue to be discovered at a rate which is declining very slightly. It now seems clear that new standards based on incidence of active cases should be substituted for the present basis of planning under the act.

2. One of the important innovations in the Hill-Burton inventory is the distinction made between acceptable and nonacceptable beds. For planning purposes, only acceptable beds are recognized as counting against total need. There is still a considerable variation among State plans as to the degree to which nonacceptable beds have been identified and taken into account for planning. As shown by table 1, nonacceptable beds today amount to about 15 percent of all existing beds in the Nation. In some States only a few such beds have been distinguished. Sometimes this arises from the assumption that facilities licensed must be held acceptable, even though there may be substantial public hazards existing. For example, Kentucky and Alabama have recorded only about 0.25 beds per 1,000 population as unacceptable, while Mississippi, Louisiana, and Virginia report 1.5 beds or more per $1,000 \mathrm{popu}$ lation as unacceptable. Three States, Georgia, Kansas, and Connecticut, have recently modified their records by increasing the designation of unacceptable beds very substantially. There is a need for the establishment of practical and comparable minimum standards of acceptability.

3. A third technical problem relates to the role of existing beds for civilians in Federal hospitals. Supporters of the viewpoint that these beds should be included in State hospital plan inventories are increasing. According to last available reports there are existing about 46,000 such general hospital beds for civilians, 55,000 mental hospital beds, and 15,000 tuberculosis hospital beds, which are not now recorded in Hill-Burton plans. These are not distributed uniformly among the States in relation to the population, and cannot all be regarded as reasonably accessible. They still constitute a considerable proportion of the total actual hospital plant. For the present they could probably be added to the record without changing the levels of total need, since many States find these goals greater than the apparent ability of their people to achieve at this time.

A second group of problems relates to broad policy for standards governing the degree of Federal assistance:

1. The Hospital Survey and Construction Act constitutes a fairly advanced form of grant-in-aid principles. It has the practical effect of producing its maximum program in States of minimum income and greatest need. Various proposals have arisen for modifying this distribution of aid among the States and also for requiring State support in addition to local support.

2. Within most States, there are marked differences among hospital areas in need and financial resources. The present Hospital Survey and Construction Act recognizes this situation. An option is provided which varies the percentage of Federal assistance on specific projects, as an alternate to selecting a single percentage for all projects in any one State. Interest in using this option is increasing, as it facilitates actual construction in remaining areas having acute need and restricted means.

\section{Summary}

1. The number of existing hospital beds provides a useful measure of the hospital services available to a community and to the Nation.

2. Continuing inventories and comprehensive State plans under the Hospital Survey and Construction Act of 1946 define total need for hospital beds and indicate a positive construction program.

3. According to these State plans (which do not include Federal beds) the United States on January 1, 1953, had 1,057,000 acceptable hospital beds for civilians, or 56 percent of the total need. The existing national plant for each category of hospital amounted to the following percentages of total need: tuberculosis 77 percent, general 69 percent, mental 56 percent, chronic 14 percent.

4. Marked differences exist among the States, and among the broad socioeconomic regions of the country, in the relative number of hospital beds available per capita. Present resources, or their lack, are closely related to the economic ability of the area. 
5. The Hill-Burton program has had a considerable impact, through 5 years of active operation, in beginning to reduce differences in unmet need for beds-locally, by States, and by broad socioeconomic regions. The total dollar value of work put in place with Hill-Burton aid has averaged about one-third of all nonFederal hospital construction. Its distribution has been both rural and urban. Although the actual number of beds for mental and chronic care has increased considerably since 1948, growth in population and the need for replacing obsolete facilities has increased the net deficit of beds needed in these categories. On the other hand, in this period the unmet need for general hospital beds was reduced by one-fourth, and for tuberculosis beds by one-half.

6. Although statewide planning for hospital construction is now accepted practice, through the encouragement of the Hill-Burton Act, there are still technical problems of defining more precisely the standards of need. Problems also remain, as to the appropriate amount and distribution of financial assistance to local communities, in order to level out deficits in hospital beds and attain facilities for the promotion of adequate health care throughout the Nation.

\section{REFERENCES}

(1) Gilbertson, Wesley E., and Kahn, Harold A.: Construction of hospitals, health centers and other health facilities, 1951-52. Pub. Health Rep. 67: 1168-1178 (1952).

(2) Reed, Louis S.: Hospital construction trends. Mod. Hosp. 78: 72-76 (1952).

(3) Cronin, John W.: What Hill-Burton has accomplished. Hosp. Prog. 34: 64-66 (1953).

\section{Training Courses in Diabetes Control}

The Division of Chronic Disease and Tuberculosis, Public Health Service, announces a series of six courses for training in diabetes control to be held at the Diabetes Study and Training Center, Boston, Mass. Designed for public health administrators, physicians, nurses, health educators, dietitians, nutritionists, medical technologists, and medical social workers, the week-long courses will consist of discussions, demonstrations, and field trips, with opportunities for individual consultation. At present only two of the courses have been scheduled. Announcements of the dates of the others will be made periodically.

The courses are as follows:

$A$ diabetes program in public health (September 21-25, 1953). Designed for all categories of public health workers involved in the planning and operation of diabetes public health programs.
Group teaching of patients (May 25-29, October 5-12, November 30December 4, 1953). Planned primarily for personnel concerned with organizing and conducting group classes for patients with diabetes and their families.

Nursing aspect of a public health diabetes program (dates to be announced). Planned for nursing personnel in health departments, voluntary agencies, hospitals, clinics and industry.

Nutritional aspects of a public health diabetes program (dates to be announced). Planned for dietitians and nutritionists in public and private health agencies and hospitals

Laboratory aspects of a public health diabetes program (dates to be announced). Intended for medical technologists in health agencies and hospitals who are concerned with methods of determination and the merits of various blood sugar tests; operation of a mass detection program; and problems associated with the collecting, shipping and storage of blood.

Organization and management of $a$ diabetes clinic (dates to be announced). Planned for personnel concerned with the functioning of a diabetes clinic. The course will be sponsored and given in cooperation with the clinical staff of a large city hospital.

Enrollment in the courses will be limited to 10 persons per course. No registration or tuition fee is required. Further information and application forms may be obtained from the Diabetes Study and Training Center, Public Health Service, 639 Huntington Avenue, Boston 15, Mass. Applications must be received 1 month in advance of date of course. 